\title{
Cost-effectiveness of Real Time Continuous Glucose Monitoring to Target Glucose Control in Preterm Infants
}

Authors: Stavros Petrou, PhD, ${ }^{1}$ Sungwook Kim, PhD, ${ }^{1}$ Simon Bond, $\mathrm{PhD},{ }^{2}$ Annabel Allison, MSc, ${ }^{2}$ Kathryn Beardsall, MD, ${ }^{3}$ and the REACT collaborative.

1 Nuffield Department of Primary Care Health Sciences, University of Oxford, Oxford, UK.

2 Cambridge Clinical Trials Unit, Cambridge University Hospitals NHS Foundation Trust, Cambridge, UK.

3 Department of Paediatrics, University of Cambridge, Cambridge, UK.

\section{Contact for correspondence:}

Stavros Petrou

Professor of Health Economics

Nuffield Department of Primary Care Health Sciences, University of Oxford

Radcliffe Observatory Quarter, Woodstock Road, Oxford, OX2 6GG

United Kingdom

Email: stavros.petrou@phc.ox.ac.uk

Telephone: (0044) 1865289503

Word count: 4554 


\begin{abstract}
The optimal management of glucose levels in critical care remains an area for research due to the problems of balancing the risks of hyperglycemia versus hypoglycemia. This paper reports the first economic evaluation of real time continuous glucose monitoring to guide the clinical management of preterm infants, based on evidence from the REACT trial. Bivariate regression of costs ( $£, 2016-17$ prices) and cases of adequate glucose control, with multiple imputation of missing data, was conducted. When the economic evaluation was restricted to the first week of life, real time continuous glucose monitoring was associated with increased costs and a statistically significant increase in adequate glucose control. When the assessment was performed over a time horizon extending to 36 weeks' corrected gestational age, real time CGM was dominant in health economic terms, i.e. associated with lower costs and better outcomes. These results largely remained robust to a range of sensitivity analyses and sub-group analyses designed to address uncertainty and heterogeneity surrounding the cost-effectiveness outcomes. This study suggests that the use of real time continuous glucose monitoring in preterm infants is associated with a high probability of costeffectiveness.
\end{abstract}

Key words: Real time continuous glucose monitoring; preterm; neonatal care; economic evaluation; cost-effectiveness 


\section{Introduction}

The optimal management of glucose levels in critical care remains an area for research enquiry due to the problems of balancing the risks of hyperglycemia versus hypoglycemia. This is a particular problem in neonatal intensive care, where high-energy nutritional requirements are needed to support growth, and variable insulin sensitivity makes infants at risk from both hyperglycemia and hypoglycemia. Both, along with extreme glucose variability, are common in these infants and have been associated with increased mortality and morbidity. ${ }^{1,2}$ One of the challenges is monitoring the rapid fluctuations in glucose levels using only intermittent blood glucose sampling. Attempts to reduce risks associated with hyperglycemia have often resulted in increased risk of hypoglycemia. ${ }^{3-5}$ Furthermore, the use of masked continuous glucose monitoring (CGM) has revealed clinically silent episodes of hypoglycemia in the newborn that are associated with worse developmental outcomes in early childhood. ${ }^{6,7}$

Hyperglycemia has been associated with acute problems of osmotic diuresis and metabolic acidosis, as well as with increased risks of intraventricular haemorrhage, patent ductus arteriosus (PDA) ${ }^{8}$, retinopathy of prematurity (ROP), and necrotizing enterocolitis (NEC)..$^{2,9-11}$ The developing brain is also vulnerable to rapid changes in glucose levels ${ }^{12}$ and hypoglycemia has been associated with occipital temporal lesions. ${ }^{11}$ Thus, early control of glucose levels may be an important modifiable risk factor for clinical outcomes in the extremely preterm infant.

Managing glucose control is currently dependent on repeated measures of blood glucose, but in the preterm infant it is important to minimize infant handling and to limit blood loss. This has resulted in a dependence on relatively infrequent intermittent blood sampling. ${ }^{13}$ The use of real time CGM in these vulnerable preterm infants could allow earlier detection and potentially prevention of exposure to extreme glucose levels.

CGM has been used in adult ${ }^{14}$ and paediatric intensive care ${ }^{15}$ to optimize glucose control, and preliminary data suggest it is feasible in preterm infants, but this has not been formally 
evaluated. ${ }^{7,16,17}$ The REAl time Continuous glucose moniToring in neonatal intensive care (REACT) project represented the first attempt to formally evaluate the use of real time CGM to guide the clinical management of preterm infants. ${ }^{18}$ In this paper, we report the first economic evaluation of real time CGM based on evidence from the REACT project.

\section{Methods}

\section{Trial Background}

REACT (ISRCTN: 12793535) was an international open label, parallel group, individually randomized controlled trial of 180 infants with birth weight $\leq 1200 \mathrm{~g}$, gestation $\leq 36$ weeks +6 days and aged $\leq 24$ hours. Infants were recruited between July 2016 and January 2019 from 13 neonatal intensive care units (NICUs) in the UK, Spain and The Netherlands and were randomized on a 1:1 ratio to either real time CGM or glucose control monitored and managed according to local standard clinical practice using intermittently sampled blood glucose levels. The primary efficacy outcome was defined by the percentage of time sensor glucose (SG) levels that were in the target range of $2.6-10 \mathrm{mmol} / \mathrm{L}(46$ to $180 \mathrm{mg} / \mathrm{dl}$ ), compared between study arms. The study protocol covering the economic evaluation was approved in the UK by the Health Research Authority (IRAS ID 168042), Research Ethics Committee (Ref: 15/EE/0158) and the Medicines and Healthcare products Regulatory Agency (Ref: $\mathrm{Cl} / 2016 / 0011$ ) as well as by all local regulatory boards. The trial was funded by the UK National Institute for Health Research Efficacy and Mechanisms Evaluation Program. Further details of the trial, its sampling procedures, and methodology and outcome measures are reported elsewhere. ${ }^{18}$

\section{Overview of economic evaluation}

The main goal of the health economic evaluation for the REACT RCT was to evaluate the comparative cost-effectiveness of the two interventions: CGM versus standard approach in infants $\leq 1200 \mathrm{~g}$ and $\leq 24$ hours of age. The economic analysis adopted a National Health Service (NHS) and personal social services (PSS) perspective, capturing services provided by health and local authorities, in accordance with National Institute for Health and Care 
Excellence (NICE) methodological recommendations. ${ }^{19}$ For the purposes of the economic evaluation, cost-effectiveness was primarily presented in terms of incremental cost per additional case of adequate glucose control during the first seven days of life for the trial participants. However, clinical data were prospectively collected until 36 weeks' corrected gestational age; as a result, the costs and secondary outcomes incurred until 36 weeks were also reflected in the cost-effectiveness analysis. Study participants were hospitalised in a $\mathrm{NICU}$ and the majority of participants were in hospital at the 36 week corrected gestational assessment. Costs and outcomes were not discounted to present values due to the short time horizon of the economic evaluation, extending to either seven days or 36 weeks' corrected gestational age.

\section{Measurement of resource use and costs}

Health economic data were collected on:

1. Resource use and costs associated with CGM (direct intervention costs)

2. Broader health service use during the 36 week follow-up period All costs were presented in British pounds sterling and valued at 2016-17 prices. If necessary, costs were inflated or deflated to 2016-17 prices using the UK NHS Hospital and Community Health Services (HCHS) Pay and Price Inflation Index. ${ }^{20}$

Direct intervention costs

Direct intervention costs encompassed the costs associated with the application of the comparator interventions, that is, CGM with guideline against standard care. In the intervention arm, infants had glucose sensors inserted, Enlite ${ }^{\mathrm{TM}}$, which were linked to a MiniMed ${ }^{\mathrm{TM}}$ 640G system and calibrated with point of care BG levels. As a result, the costs of the intervention included the cost of the Enlite ${ }^{\mathrm{TM}}$ sensor (MiniMed ${ }^{\mathrm{TM}}$ system), the costs associated with fitting the device to infants (hospital staff time), the costs associated with removal of sensors, and the cost of point of care glucose for calibration. The lifetime cost of the Medtronic system was annuitized and then further adjusted to reflect the time use of the device over the trial period. However, in order to reflect clinical practice outside the confines of a RCT, the resource inputs associated with masked continuous glucose monitoring and 
the use of associated devices were not costed in the control arm although the relevant resource inputs were prospectively measured. The resource use associated with the direct intervention costs was collected prospectively. Table 1 provides an outline of the types of direct intervention-related resource inputs that were measured, and the sources for the respective unit costs of each resource input.

Cost estimates for staff inputs associated with key clinical events, such as time associated with sensor insertion and removal, were based on expert clinical advice about the duration of each event and the unit cost values for staff inputs were obtained from the NHS Agenda for Change 2016/17 pay scales. ${ }^{21}$ The total direct intervention cost for each participant was estimated by estimating the compound of the associated resource use input values multiplied by their respective unit cost values.

\section{Measuring broader resource use}

The different types of resource categories for broader healthcare costs and their respective sources of unit costs are presented in Table 2.

Broader resource use data were collected for each infant using data extraction sheets completed by research nurses in each clinical centre who extracted the relevant data directly from routine hospital systems and patient records, following the final follow-up assessments at 36 weeks' corrected gestational age. The case report forms (CRFs) recorded details of length of inpatient stays by intensity of care, investigations performed (e.g. ultrasound scans, MRIs, ECGs, CT scans, X-rays, cranial ultrasound scans, EEGs), medications, and procedures performed (e.g. lumbar punctures, ventricular taps, long lines, surgeries, and interventions for ROP treatment). They also captured information surrounding transfers between hospitals and modes of transport used for hospital transfers and at final hospital discharge. Furthermore, where applicable, they captured resource use in hospitals that infants were transferred to. Distances associated with transfers between hospitals were calculated using Google Maps. 


\section{Valuation of resource use}

Unit cost data were mainly obtained using the Department of Health and Social Care's Reference Costs 2016-7 schedules. ${ }^{22}$

Costs for sensor insertion, sensor monitoring, and sensor removal were calculated by applying clinical advice on the time taken for each activity; their respective unit costs were extracted from the NHS Agenda for Change 2016/17 pay scales and applied to the duration of each activity. Costs of medications for infants were estimated based on the doses and frequencies reported on the CRF with medication costs obtained from the British National Formulary (BNF). ${ }^{23}$ Costs of blood transfusion products such as platelets, red blood cells, and frozen plasma were obtained from NHS Blood and Transplant price list ${ }^{24}$ and applied to the volume of use for each product.

When infants were transferred to another hospital, the distance between the study site and transferred location (miles) was calculated using Google maps and we applied fuel costs that were calculated using the Advisory Fuel Rates (AFR) obtained from UK government. ${ }^{25}$ The fuel costs applied to the distances of hospital transfers in clinical sites located outside the UK were estimated in the same manner.

\section{Measurement of outcomes}

The primary clinical outcome measure for this study was the percentage of time SG readings fell in the target range of $2.6-10 \mathrm{mmol} / \mathrm{l}(46$ to $180 \mathrm{mg} / \mathrm{dl})$, within the first seven days of life. Cost-effectiveness was primarily expressed in terms of incremental cost per additional case of adequate glucose control during the first seven days of life. For the primary cost-effectiveness analysis, adequate glucose control was defined a priori by the REACT clinical team as at least $80 \%$ of readings falling within the target range. However, in order to assess the robustness of the cost-effectiveness results, a number of sensitivity analyses were also performed that varied the threshold for number of readings falling within the target range of $2.6-10 \mathrm{mmol} / /$; hence, adequate glucose control was re-estimated at alternative thresholds of $60 \%, 70 \%$, and $90 \%$ of readings falling within the target range with the alternative thresholds defined a priori. Given the nature of the outcome measure used in 
this project and the methodological constraints surrounding utility measurement in newborn infants, cost-utility analysis using a preference-based measure such as quality-adjusted life years (QALYs) was not performed.

The secondary clinical outcome measures selected for secondary expressions of costeffectiveness were NEC and bronchopulmonary disease (BPD) on the basis of animal and human evidence linking hyperglycemia with morbidity. Cost-effectiveness analyses using these secondary clinical outcome measures were also expressed using an incremental costeffectiveness ratio (ICER) and expressed in terms of incremental cost per case of NEC averted, and incremental cost per case of BPD averted, using imputed costs for the entire period extending to 36 weeks' corrected gestation.

\section{Cost-effectiveness analysis methods}

\section{$\underline{\text { Missing data }}$}

Missing data may be a particular issue for costs and the health outcome measures of interest and therefore it is required to deal with them in a standardised way. Within the health economic literature, RCTs have been criticised for failing to use appropriate methods to address missing data. ${ }^{26}$

Multiple imputation was adopted to impute missing data and avoid biases associated with complete case analysis. Multiple imputation was conducted based on Rubin's rule. ${ }^{27}$ Multiple imputation was carried out on the main and secondary clinical outcome measures, using Markov chain Monte Carlo (MCMC) and predicted mean matching (PMM). ${ }^{28} \mathrm{PMM}$ is a semiparametric imputation approach, and generally performs better than linear regression despite the similarities in method. ${ }^{29}$

It is recommended that potential predictors are incorporated into analytical models for multiple imputation. ${ }^{29}$ Inclusion of explanatory variables enables the analyst to use multiple imputation by chained equations (MICE). In chained equations, missing values in variable $X$ are replaced by draws from the posterior predictive distribution of $X$ and imputation is repeatedly performed using the values of other independent variables. ${ }^{30}$ Consequently, the multiple imputation models used baseline covariates (gestational age, gender, site, 
randomisation arm), as well as health outcomes and cost components (glucose level, and costs associated with inpatient days, investigation, medical treatment, and surgical procedures).

For the CGM outcome, before implementing multiple imputation, linear interpolation using the known values of CGM before and after any missing values was firstly conducted given that the data followed a time series format. ${ }^{31}$ Interpolation requires that the dependent variable be a function of independent variables, so glucose level was also interpolated for values of the time that glucose level was checked. ${ }^{31,32}$ Then, likewise, the interpolated values were imputed using a chained equation with baseline covariates and costs. Five imputed datasets were generated as this has been considered to be sufficient to obtain valid results. ${ }^{28}$

\section{$\underline{\text { Regression analysis }}$}

Generalised linear modelling (GLM) was used to estimate total costs and effectiveness. GLM is an estimation strategy well suited to modelling skewed data. ${ }^{33}$ Exponentiation of the mean of the logs generates the geometric mean of the skewed dependent variable (in this case costs), which is a downward-biased estimate of the arithmetic mean. ${ }^{34}$ In contrast, GLM predicts the mean of the log without using a smearing factor and thus tends to yield more consistent results. After conducting statistical tests such as the Pregibon link test and Pearson correlation test on cost data, the gamma family and log link function were chosen as an appropriate GLM form for the trial data.

By specifying the treatment group as an indicator within the GLM model, the incremental costs and outcomes attributable to CGM were estimated, whilst controlling for baseline covariates (treatment arm, study site, gestational age, gender, birth weight standard deviation score, whether the mother received antenatal steroids $>24$ hours prior to delivery, and whether the mother had diabetes during pregnancy).

Presentation of cost-effectiveness results

Summary statistics were estimated for resource use variables by treatment allocation and duration, either covering days one to seven, or the 36 week follow-up period. Between 
treatment group differences in resource use and costs were initially compared using the twosample t-test. Standard errors are reported for CGM and control group means. Mean differences are reported with $95 \%$ confidence intervals (Cls). Where there was evidence of non-normality in the continuous outcome measure, non-parametric bootstrapping, with 1000 samples, was used to estimate the effect of the intervention and bootstrapped $95 \%$ Cls for mean differences are reported. Cost-effectiveness was estimated using a bootstrap method to minimise sampling uncertainty. Nonparametric bootstrap methods generate multiple replications of the statistic of interest by sampling replications from the original data. ${ }^{35,36} \mathrm{~A}$ total of 1000 bootstrap samples were drawn and incremental cost-effectiveness with associated $95 \%$ Cls were calculated. Estimates from each imputed dataset were used to run regressions using Rubin's rule. ${ }^{35}$

In order to express uncertainty around ICERs, and to show results across a range of cost-effectiveness thresholds, cost effectiveness acceptability curves (CEACs) were also generated on the basis of bootstrapped sample data. ${ }^{37,38}$ These curves show the probability that CGM is cost-effective at different levels of the cost-effectiveness threshold based upon modelled variation in observed patient outcomes. ${ }^{37}$

To determine cost-effectiveness, CGM was compared to the standard approach on the basis of the cost per additional case of adequate glucose control. An alternative that is less effective and more costly, on average, than one (or a linear combination) of other alternatives is considered 'dominated' in health economic terms and therefore not considered when estimating ICERs. An alternative that is most effective (i.e. provides greatest additional adequate glucose control) and offers an ICER less than or equal to a benchmark value (the cost-effectiveness threshold) can be deemed 'cost-effective' compared to other alternatives. ${ }^{39}$ However, there are currently no published costeffectiveness thresholds for the primary and secondary clinical outcomes of the REACT trial. In addition, we searched the stated and revealed preference literature to identify any external evidence with respect to population preferences for health changes associated with adequate glucose control and for health changes associated with the secondary clinical 
outcomes. No such preference values were revealed by our literature searches and hence ranges of hypothetical cost-effectiveness threshold values have been selected for our analyses. As a result, the net monetary benefit (NMB) of using CGM versus standard approach was also calculated across three pre-determined cost-effectiveness thresholds, namely $£ 1,000, £ 5,000$, and $£ 10,000$ per additional case of adequate glucose control. ${ }^{39}$ Additionally, alternative cost-effectiveness threshold values were introduced for the secondary outcome analyses based on both the NEC and BPD outcomes $(£ 10,000, £ 30,000$ and $£ 50,000$ cost-effectiveness thresholds). A positive incremental NMB indicates that the CGM is cost-effective compared with the standard approach at the given cost-effectiveness threshold.

\section{Sensitivity, sub-group and secondary outcomes analyses}

Several sensitivity analyses were carried out to assess the robustness of the costeffectiveness estimates. These were conducted under the following scenarios: (1) restricting the analyses to complete cases (i.e. those with complete cost and outcome data for the seven days or up to 36 weeks' corrected gestation); and (2) estimating incremental costeffectiveness using different thresholds for adequate glucose control of $60 \%, 70 \%$, and $90 \%$. The same sensitivity analyses described above were repeated over alternative follow-up periods of the first seven days of life or extending to 36 weeks' corrected gestational age for the assessment of economic costs.

Two sets of pre-specified sub-group analyses were conducted to explore the heterogeneity in the cost-effectiveness results. Sub-group analysis was performed for each study site and for two gestational age groups: extremely preterm ( $<28$ weeks) and very preterm (28 weeks to 32 weeks). A post-hoc sub group analysis was subsequently carried out using gender as an additional sub group category. All sub-group analyses were based on cases with imputed cost and outcomes data at seven days or 36 weeks' corrected gestational age. Cost-effectiveness outcomes were also re-estimated using the secondary outcomes of NEC and BPD. 


\section{Results}

One hundred and eighty infants were randomized to ether real time CGM $(n=85)$ or standard clinical practice $(n=95)$. The REACT clinical results are reported in full elsewhere. ${ }^{18}$

\section{Economic costs}

Table 3 summarises the total NHS and PSS costs associated with resource use during days one to seven, day 8 to 36 weeks' corrected gestation, and the entire study period, for complete cases. The mean direct intervention costs were $£ 11,198$ for CGM compared with $£ 9,934$ for the standard approach over the first seven days; however, the mean unadjusted cost difference was not statistically significant at the $5 \%$ level. The cost of using the Enlite ${ }^{\mathrm{TM}}$ sensor and glucose monitoring was not counted for in the control arm, as it is not part of standard care. The total cost during the period covering day 8 to 36 gestational weeks was higher for the control arm, $£ 61,065$ versus $£ 65,464$, but this was not statistically significant at the $5 \%$ level. The main driver for the higher cost in the control arm during this period of follow up was the higher cost of neonatal care (mean length of stay in intensive care: 13.2 versus 16.7 days). Likewise, the mean total NHS and PSS cost throughout the entire followup period was higher for the control group $(£ 75,348)$ than for CGM $(£ 71,909)$; and the mean between-group cost difference was $£ 3,439$, but was not statistically significant at the $5 \%$ level.

\section{Cost-effectiveness results}

The cost-effectiveness results are presented in Table 4 and Table 5 for days one to seven, and the entire study period, respectively. The associated CEAC is graphically represented in Figure 1.

\section{Base case analysis}

Two base-case analyses were performed; firstly, imputed seven day intervention costs and cases of adequate glucose control as shown in Table 4 (with an $80 \%$ threshold selected for definition of adequate glucose control), and secondly, imputed costs and cases of 
adequate glucose control ( $80 \%$ threshold) but with costs extending to 36 weeks' corrected gestational age and outcomes restricted to the intervention period (Table 5). For the first base-case analysis, trial participants in the CGM arm experienced a statistically significant increase in cases of adequate glucose control based on 1000 times bootstrap simulations (23\% point increase in adequate glucose control) for the first seven day intervention period. Mean NHS and PSS costs (Table 4) were also lower in the control group (mean cost difference: £605). The ICER for the base-case analysis in Table 4 indicates that CGM is, on average, more costly and more effective. Assuming cost-effectiveness thresholds of $£ 1,000$, $£ 5,000$, and $£ 10,000$ per additional case of adequate glucose control, respectively, the probability of cost-effectiveness for CGM reaches $90 \%$ at approximately $£ 6,000$ whilst the NMB associated with CGM became positive at a cost-effectiveness threshold of $£ 5,000$.

For the second base case analysis in Table 5, the trial participants in the intervention arm experienced lower costs (mean cost difference: $£ 2,877$ ) and a $23 \%$ point increase in cases of adequate glucose control as before. CGM was not only less costly but also the more effective strategy in this second base case analysis and therefore dominant in health economic terms. To summarise, the base case analyses reported in Table 5 show that CGM is the dominant strategy in health economics terms.

Sensitivity analyses

The cost-effectiveness outcomes generated by the sensitivity analyses using different analytical scenarios (complete case, imputed costs with 60\%, $70 \%$ and $90 \%$ thresholds selected for definitions of additional adequate glucose control) generally supported the base case findings. For the complete case analysis in Table 4, mean costs were higher in the CGM group (mean cost difference: $£ 1,104,95 \% \mathrm{Cl}:-38.56$ to $2,247.11$ ). The effectiveness results followed the same pattern as that for the base case analysis and showed that participants in the CGM experienced a statistically significant increase in proportion of glucose readings within the target range over the seven day intervention period $(0.22 ; 95 \%$ Cl: 0.05 to 0.4 ). For the four sets of sensitivity analyses in Table 4, the probabilities of costeffectiveness of CGM reached approximately $90 \%$ at cost-effectiveness thresholds of 
$£ 10,000$. Adopting $60 \% 70 \%$ and $90 \%$ thresholds for proportions of glucose readings within the target range, the costs for each group remained identical at $£ 10,354$ for the CGM group and $£ 9,749$ for the control group, whilst estimates of effectiveness varied. However, the pattern of increased effectiveness of CGM remained consistent across the scenarios using different levels of adequate glucose thresholds. The results presented in Table 5 support this finding. The notable difference is that CGM becomes the dominant strategy in health economic terms in the sensitivity analyses in Table 5 due to the lower costs of CGM compared with the standard approach. In brief, the sensitivity analyses generally support the findings of the base case analyses.

\section{$\underline{\text { Sub-group analyses }}$}

Sub-group analyses were performed using the variables of: site, gestational age, and gender. For sites, a few study sites were dropped due to the insufficient numbers of observations in the study sites. In all the study sites presented in Table 4, effectiveness was greater for the CGM group than the standard approach and costs were also higher other than in site no N42 (Norwich). Sub-group analyses based on gestational age at birth and gender demonstrated the same pattern that costs and effectiveness were generally higher for CGM than standard care. Another notable finding was that costs were lower for males in the sub-group analyses.

\section{Secondary outcome analyses}

Using the two outcomes of NEC and BPD, secondary outcome analyses were performed. For these outcomes, increased effectiveness can be interpreted as reduced cases of NEC and BPD, and hence the denominator of the incremental cost-effectiveness ratio has been inverted. The secondary outcome analyses revealed that CGM averts more cases of BPD and NEC with higher costs than the standard approach when the assessment of economic costs was restricted to the seven day intervention period. Different costeffectiveness threshold values were adopted for the secondary outcome analyses, namely $£ 10,000, £ 30,000$ and $£ 50,000$. In Table 5, the secondary outcomes revealed that the probability of cost effectiveness for CGM reached $80 \%$ at a $£ 10,000$ cost effectiveness 
threshold. In the secondary analyses reported in Table 4, mean costs were higher in the CGM group (mean cost difference: $£ 605,95 \% \mathrm{Cl}$ : -379 to 1589). When both costs and outcomes were valued over a time horizon extending to 36 weeks' corrected gestational age (Table 5), estimates of effectiveness followed the same pattern as the base case analysis but the costs were lower for CGM (mean cost difference: $£-2,877,95 \% \mathrm{Cl}:-10,026$ to 4,272 ), making CGM dominant in health economic terms.

\section{Discussion}

This paper reports the first economic evaluation of real time CGM in neonatal intensive care. The study revealed that when the assessment was restricted to the first week of life, real time CGM was associated with increased costs and a statistically significant increase in adequate glucose control. When the assessment was performed over the extended time horizon that mirrored the time horizon of the trial, real time CGM was dominant in health economic terms. These results largely remained robust to a range of sensitivity analyses and sub-group analyses designed to address uncertainty and heterogeneity surrounding the cost-effectiveness outcomes and, separately, when the secondary clinical outcomes of cases of BPD and NEC averted were considered.

Previous economic evaluations of real time CGM were conducted in clinical contexts outside of neonatal intensive care and therefore, a comparative assessment of costeffectiveness evidence is not possible. ${ }^{40-42}$ Moreover, prior to REACT, previous studies of real time CGM in infants had been restricted to a small number of extremely preterm infants. ${ }^{9,43}$ Our data should, therefore, be of relevance to clinical decision-makers and service planners tasked with preventing the adverse sequelae of hyperglycemia, hypoglycemia, and glycaemic instability in preterm infants.

The economic evaluation reported in this paper was conducted according to nationally agreed design and reporting guidelines. ${ }^{19,44}$ It was based on a randomised, multi-centre, controlled trial that avoided many of the selection biases that characterise observational studies and that provided a vehicle for comprehensive prospective assessments of resource 
use and clinical outcomes. The study's cost accounting was rigorous and included all significant resource items calculated from a NHS and PSS perspective. A comprehensive analytical strategy was pursued to handle sampling uncertainty surrounding the baseline ICERs, methodological uncertainty surrounding design features of the economic evaluation, and decision uncertainty surrounding the value of the cost-effectiveness threshold. Readers should, however, consider caveats when interpreting the study results. First, the time horizon for the economic evaluation was restricted to the time horizon of the trial, extending to 36 weeks' corrected gestational age. The effects of real-time CGM for targeting glucose control in neonates on longer-term economic costs and health consequences, including its potential preventive effects of the sequelae of NEC and BPD, remains a topic for future research. This includes the requirement to develop a decision-analytic model as a basis for estimating longterm cost-effectiveness. Second, and in parallel, by adopting the recommended NHS and PSS perspective ${ }^{19}$ the economic evaluation excluded broader costs, such as costs borne by family members and informal carers. It is likely that incorporation of these broader societal costs would improve the relative long-term cost-effectiveness of real time CGM if larger studies confirm that it reduces the risk of pathologies such as NEC and BPD that are predictive of poor neurodevelopmental outcomes. Third, the effectiveness of real time CGM has not been measured in terms of a preference-based outcome measure, such as the QALY, for which external cost-effectiveness threshold values are available and which may have been more useful for comparative purposes. ${ }^{19}$ This had the effect that we had to rely on arbitrary cost-effectiveness threshold values for achieving an additional case of adequate glucose control. Preference elicitation techniques developed by economists, such as the willingness to pay approach and stated preference discrete choice experiment methods could, in principle, be used to estimate individual and population preferences for the clinical sequelae of real time CGM. ${ }^{45}$

In conclusion, this study suggests that the use of real time CGM in preterm infants is associated with a high probability of cost-effectiveness. Decision-makers should consider the likely economic impacts of its implementation in routine clinical practice. 


\section{Acknowledgments}

We acknowledge funding provided by the UK National Institute for Health Research EME Program and supported by The National Institute for Health Research Cambridge Biomedical Research Centre and the Cambridge Clinical Trials Unit, and through the Portfolio from NIHR CRN Eastern. Donations of equipment were received from Medtronic and Nova Biomedical. Neither Medtronic nor Nova Biomedical had any role in design of the study, gathering of data, access to data, or preparation of the manuscript or decision to publish the results.

\section{Competing interests}

All authors state that they have no financial relationships or competing interests relevant to this article to declare. 


\section{References}

1. Sinclair JC, Bottino M, Cowett RM. Interventions for prevention of neonatal hyperglycemia in very low birth weight infants. Cochrane Database Syst Rev 2011; (10): CD007615.

2. Hays SP, Smith EO, Sunehag AL. Hyperglycemia is a risk factor for early death and morbidity in extremely low birth-weight infants. Pediatrics 2006; 118(5): 1811-8.

3. Van den Berghe $G$, Wouters $P$, Weekers $F$, et al. Intensive insulin therapy in critically ill patients. N Engl J Med 2001; 345: 1359-67.

4. Vlasselaers D, Milants I, Desmet L, et al. Intensive insulin therapy for patients in paediatric intensive care: a prospective, randomised controlled study. Lancet 2009; 373(9663): 547-56.

5. Alsweiler JM, Harding JE, Bloomfield FH. Tight glycemic control with insulin in hyperglycemic preterm babies: a randomized controlled trial. Pediatrics 2012; 129(4): 639-47.

6. McKinlay CJD, Alsweiler JM, Anstice NS, et al. Association of neonatal glycemia with neurodevelopmental outcomes at 4.5 years. JAMA Pediatr 2017; 171(10): 972-83.

7. Beardsall K, Vanhaesebrouck S, Ogilvy-Stuart AL, et al. Early insulin therapy in verylow-birth-weight infants. N Engl J Med 2008; 359(18): 1873-84.

8. Finberg L. Dangers to infants caused by changes in osmolal concentration. Pediatrics 1967; 40(6): 1031-4.

9. Garg R, Agthe AG, Donohue PK, Lehmann CU. Hyperglycemia and retinopathy of prematurity in very low birth weight infants. J Perinatol 2003; 23(3): 186-94.

10. Kao LS, Morris BH, Lally KP, Stewart CD, Huseby V, Kennedy KA. Hyperglycemia and morbidity and mortality in extremely low birth weight infants. J Perinatol 2006; Dec 26(12): 730-6. 
11. Yager JY. Hypoglycemic injury to the immature brain. Clin Perinatol 2002; 29(4): 65174 , vi.

12. Alexandrou G, Skiold B, Karlen J, et al. Early hyperglycemia is a risk factor for death and white matter reduction in preterm infants. Pediatrics 2010; 125(3): e584-91.

13. Beardsall K. Measurement of glucose levels in the newborn. Early Hum Dev2010; 86(5): 263-7.

14. Leelarathna L, English SW, Thabit $\mathrm{H}$, et al. Accuracy of subcutaneous continuous glucose monitoring in critically ill adults: improved sensor performance with enhanced calibrations. Diabetes Technol Ther 2014; 16(2): 97-101.

15. Bridges BC, Preissig CM, Maher KO, Rigby MR. Continuous glucose monitors prove highly accurate in critically ill children. Crit Care 2010; 14(5): R176.

16. Beardsall K, Ogilvy-Stuart AL, Ahluwalia J, Thompson M, Dunger DB. The continuous glucose monitoring sensor in neonatal intensive care. Arch Dis Child Fetal Neonatal Ed 2005; 90(4): F307-10.

17. Beardsall K, Vanhaesebrouck S, Ogilvy-Stuart AL, et al. Prevalence and determinants of hyperglycemia in very low birth weight infants: cohort analyses of the NIRTURE study. $J$ Pediatr 2010; 157(5): 715-9 e1-3.

18. Beardsall K, Thomson L, Guy C, et al., on behalf of the REACT collaborative. A randomised controlled trial of real time continuous glucose monitoring in neonatal intensive care. Submitted to JAMA Pediatrics.

19. National Institute for Health and Care Excellence (NICE). Guide to the methods of technology appraisal 2013. NICE Process and Methods Guides. NICE: London, UK; 2013

20. Curtis LA, Burns A. Unit costs of health and social care 2017. Available from: https://www.pssru.ac.uk/project-pages/unit-costs/unit-costs-2017/. Accessed on $1^{\text {st }}$ August 2019. 
21. NHS. NHS agenda for change 2017. Available from: https://www.nhsemployers.org/paypensions-and-reward/agenda-for-change/pay-scales/annual. Accessed on December $1^{\text {st }}$ 2018

22. NHS. Reference costs 2017. Available from: https://data.gov.uk/dataset/489e83d27b05-41e1-b8f3-c06c1a8a9de4/health-trust-reference-costs-2016-17. Accessed on December $1^{\text {st }} 2018$.

23. NHS. British National Formulary 2018 Available from: https://bnf.nice.org.uk. Accessed on $1^{\text {st }}$ August 2018.

24. NHS. NHS blood and transplant price list 2017 Available from:

https://www.gov.uk/government/publications/nhs-blood-and-transplant-annual-reportand-accounts-2017-to-2018. Accessed on 15 ${ }^{\text {th }}$ August 2018.

25. GOV.UK. How Advisory Fuel Rates are calculated 2019 Available from: http://www.gov.uk/government/publications/advisory-fuel-rates/how-advisory-fuel-ratesare-calculated. Accessed on $1^{\text {st }}$ August 2019.

26. Gomes M, Ng ES, Grieve R, Nixon R, Carpenter J, Thompson SG. Developing appropriate methods for cost-effectiveness analysis of cluster randomized trials. Med Decis Making. 2012;32(2):350-61.

27. Rubin DB. Multiple imputation for nonresponse in surveys: John Wiley \& Sons; 2004.

28. van Buuren S, Groothuis-Oudshoorn K. MICE: Multivariate imputation by chained equations in R. J Stat Softw. 2011;45(3):1-67.

29. Horton NJ, Lipsitz SR. Multiple imputation in practice: comparison of software packages for regression models with missing variables. Am Stat. 2001;55(3):244-54.

30. White IR, Royston P, Wood AM. Multiple imputation using chained equations: Issues and guidance for practice. Stat Med. 2011;30(4):377-99.

31. Cox N. Speaking Stata: A set of utilities for managing missing values. Stata Journal. $2015 ; 15(4): 1174-85$.

32. Moler C. Numerical computing with Matlab. Philadelphia, USA: SIAM (Society for Industrial and Applied Mathematics); 2004. 
33. Glick H, Doshi JA, Sonnad SS, Polsky D. Economic evaluation in clinical trials. Second edition. Oxford: Oxford University Press, 2014.

34. Efron B, Tibshirani R. An introduction to the bootstrap. New York: Chapman \& Hall; 1993. xvi, 436 p. p.

35. Rubin DB. Multiple imputation for nonresponse in surveys. New York: John Wiley \& Soncs Inc., 2004, 287 pages.

36. Briggs AH, Claxton K, Sculpher MJ. Decision modelling for health economic evaluation. Oxford: Oxford University Press; 2006. 237 pages.

37. Fenwick E, O'Brien BJ, Briggs A. Cost-effectiveness acceptability curves--facts, fallacies and frequently asked questions. Health Econ. 2004;13(5):405-15.

38. Drummond MF, Sculpher MJ, Claxton K, Stoddart GL, Torrance GW. Methods for the economic evaluation of health care programmes. Oxford: Oxford University Press; 2015.

39. Claxton K, Martin S, Soares M, Rice N, Spackman E, Hinde S, et al. Methods for the estimation of the National Institute for Health and Care Excellence cost-effectiveness threshold. Health Technol Assess. 2015;19(14):1-503, v-vi.

40. Fonda SJ, Graham C, Munakata J, Powers JM, Price D, Vigersky RA. The costeffectiveness of real-time continuous glucose monitoring (RT-CGM) in type 2 diabetes. $J$ Diabetes Sci Technol. 2016;10(4):898-904.

41. Conget I, Martín-Vaquero P, Roze S, et al. Cost-effectiveness analysis of sensoraugmented pump therapy with low glucose-suspend in patients with type 1 diabetes mellitus and high risk of hypoglycemia in Spain. Endocrinol Diabetes Nutr. 2018;65(7):380-386

42. García-Lorenzo B, Rivero-Santana A, Vallejo-Torres L, et al. Cost-effectiveness analysis of real-time continuous monitoring glucose compared to self-monitoring of blood glucose for diabetes mellitus in Spain. J Eval Clin Pract. 2018;24(4):772-781.

43. Thomson L, Elleri D, Bond S, Howlett J, Dunger DB, Beardsall K. Targeting glucose control in preterm infants: pilot studies of continuous glucose monitoring. Arch Dis Child Fetal Neonatal Ed. 2019;104(4):F353-F359. 
44. Husereau D, Drummond M, Petrou S, et al. Consolidated Health Economic Evaluation Reporting Standards (CHEERS)--explanation and elaboration: a report of the ISPOR Health Economic Evaluation Publication Guidelines Good Reporting Practices Task Force. Value Health 2013;16:231-50.

45. Brazier J, Ratcliffe J, Salomon J, Tsuchiya A. Measuring and valuing health benefits for economic evaluation. Oxford: Oxford University Press; 2007. 
Table 1: Direct intervention-related resource inputs and sources of unit costs

\begin{tabular}{|c|c|c|}
\hline Resource type & Resource use & Unit cost source \\
\hline Medtronic $^{\mathrm{TM}}$ 640G system and Enlite ${ }^{\mathrm{TM}}$ sensors & $\begin{array}{r}\text { Cost of 640G system and } \\
\text { Enlite }^{\mathrm{TM}} \text { sensors }\end{array}$ & Manufacturers \\
\hline Enlite $^{\mathrm{TM}}$ sensor insertion and set up of MiniMed ${ }^{\mathrm{TM}}$ & Staff time & $\begin{array}{r}\text { NHS agenda for change }{ }^{20.21} \& \text { clinician's } \\
\text { advice }\end{array}$ \\
\hline Sensor Glucose Monitoring & Staff time & $\begin{array}{r}\text { NHS agenda for change }{ }^{20.21} \& \text { clinician's } \\
\text { advice }\end{array}$ \\
\hline Removal of sensor & Staff time & $\begin{array}{r}\text { NHS agenda for change }{ }^{20.21} \& \text { clinician's } \\
\text { advice }\end{array}$ \\
\hline Point of care (Nova StatStrip ${ }^{\circledR}$ ) & Cost of Nova Biomed devices & Manufacturers \\
\hline
\end{tabular}


Table 2: Broader resource inputs and source of unit costs

\begin{tabular}{|c|c|c|}
\hline Resource type & Resource use & Unit cost source \\
\hline $\begin{array}{l}\text { Length of stay by level of care } \\
\text { (e.g. intensive care, special care) }\end{array}$ & $\begin{array}{r}\text { Staff salaries, on-costs, equipment, } \\
\text { consumables and revenue and } \\
\text { capital overheads }\end{array}$ & NHS Reference Costs ${ }^{22}$ \\
\hline Medications & Cost of medications & British National Formulary $(B N F)^{23}$ \\
\hline Investigations & $\begin{array}{l}\text { Staff time to deliver the } \\
\text { investigations, associated costs }\end{array}$ & NHS Reference Costs ${ }^{22}$ \\
\hline Medical (surgical) treatment & $\begin{array}{r}\text { Staff time to deliver treatment, } \\
\text { associated costs }\end{array}$ & NHS Reference Costs ${ }^{22}$ \\
\hline Blood transfusion products & Cost of blood transfusion products & $\begin{array}{r}\text { NHS Blood and transplant price } \\
\text { list }^{24}\end{array}$ \\
\hline Surgical procedures & $\begin{array}{r}\text { Staff time to deliver the interventions, } \\
\text { associated costs }\end{array}$ & $\begin{array}{r}\text { NHS Reference Costs NHS } \\
\text { agenda for change }{ }^{21.22}\end{array}$ \\
\hline Mode of discharge & $\begin{array}{r}\text { Mode and distance of transfer or } \\
\text { discharge to home }\end{array}$ & UK government ${ }^{25}$ \\
\hline
\end{tabular}


Table 3: Cost differences between trial arms by follow-up period and cost category; complete cases (£, 2016-17 prices)

\begin{tabular}{|c|c|c|c|c|c|c|c|}
\hline $\begin{array}{c}\text { Costs } \\
\text { (Day } 1 \text { to day } 7 \text { ) }\end{array}$ & $\begin{array}{l}\text { Intervention } \\
\quad(N=71)\end{array}$ & $\begin{array}{l}\text { Control } \\
(\mathrm{N}=83)\end{array}$ & $\begin{array}{c}\text { Total } \\
(\mathrm{N}=154)\end{array}$ & $\begin{array}{c}\text { Mean } \\
\text { difference }\end{array}$ & Parametric $95 \%$ Cl & P- value & $\begin{array}{c}\text { Bootstrap } \\
95 \% \mathrm{Cl}\end{array}$ \\
\hline & Mean (SE) & Mean (SE) & Mean (SE) & & & & \\
\hline Equipment & $87(2)$ & $\mathrm{n} / \mathrm{a}$ & $\mathrm{n} / \mathrm{a}$ & $\mathrm{n} / \mathrm{a}$ & $\mathrm{n} / \mathrm{a}$ & $\mathrm{n} / \mathrm{a}$ & $\mathrm{n} / \mathrm{a}$ \\
\hline Monitoring & $165(6)$ & $\mathrm{n} / \mathrm{a}$ & $\mathrm{n} / \mathrm{a}$ & $\mathrm{n} / \mathrm{a}$ & $\mathrm{n} / \mathrm{a}$ & $\mathrm{n} / \mathrm{a}$ & $\mathrm{n} / \mathrm{a}$ \\
\hline Point of care testing & $6(0.3)$ & $5(0.3)$ & $5(0.2)$ & 1.4 & $(0.6,2.2)$ & 0.001 & $(0.6,2.2)$ \\
\hline Length of stay & $8656(97)$ & $8534(132)$ & $8590(84)$ & 121 & $(-213,455)$ & 0.5 & $(-172,482)$ \\
\hline Medications & $79(2)$ & $77(1)$ & $78(1)$ & 2.8 & $(-2.8,5.3)$ & 0.5 & $(-3.3,4.9)$ \\
\hline Investigation & $571(31)$ & $630(33)$ & $603(23)$ & -59 & $(-148,31)$ & 0.2 & $(-148,32)$ \\
\hline Blood transfusion products & $2(2)$ & $35.7(34)$ & $20(19)$ & -34 & $(-108,39)$ & 0.8 & $(-132,2)$ \\
\hline Medical treatment & $92(17)$ & $106(18)$ & $100(12)$ & -14 & $(-63,35)$ & 0.4 & $(-68,35)$ \\
\hline Surgical procedures & $544(57)$ & $527(62)$ & $535(43)$ & 17 & $(-153,186)$ & 0.6 & $(-139,196)$ \\
\hline Other procedures & $2(2)$ & $36(34)$ & $20(19)$ & -34 & $(-108,39)$ & 0.4 & $(-144,3)$ \\
\hline Total & $11199(976)$ & 9934 (184) & 10517 (462) & 1265 & $(68,4168)$ & 0.2 & $(-560,3090)$ \\
\hline \multirow[t]{2}{*}{$\begin{array}{c}\text { Costs } \\
\text { (Day } 8 \text { to } 36 \text { weeks' corrected } \\
\text { gestation) }\end{array}$} & $\begin{array}{l}\text { Intervention } \\
\quad(\mathbf{N}=71)\end{array}$ & $\begin{array}{l}\text { Control } \\
(\mathrm{N}=82)\end{array}$ & $\begin{array}{c}\text { Total } \\
(\mathrm{N}=153)\end{array}$ & $\begin{array}{c}\text { Mean } \\
\text { difference }\end{array}$ & Parametric $95 \%$ Cl & P-value & $\begin{array}{c}\text { Bootstrap } \\
95 \% \mathrm{Cl}\end{array}$ \\
\hline & Mean (SE) & Mean (SE) & Mean (SE) & & & & \\
\hline Length of stay & $59901(2296)$ & 62807 (2059) & $61458(1533)$ & -2906 & $(-8983,3170)$ & 0.3 & $(-9020,2400)$ \\
\hline Medication - insulin only & $0.3(0.1)$ & $0.2(0.1)$ & $0.2(0.1)$ & 0.1 & $(-0.1,0.4)$ & 0.2 & $(-0.1,0.4)$ \\
\hline Investigation & $677(76)$ & $841(97)$ & $765(63)$ & -165 & $(-414,84)$ & 0.2 & $(-443,53)$ \\
\hline Blood transfusion products & $222(34)$ & $279(39)$ & $252(26)$ & -57 & $(-161,47)$ & 0.3 & $(-157,52)$ \\
\hline Medical treatment & $244(64)$ & $531(105)$ & $398(65)$ & -287 & $(-540,-35)$ & 0.03 & $(-535,-65)$ \\
\hline Surgical procedures & $20(14)$ & 909 (837) & $496(449)$ & -889 & $(-2667,889)$ & 0.3 & $(-3289,-21)$ \\
\hline Other procedures & $0(0)$ & $94(62)$ & $50(33)$ & -94 & $(-225,38)$ & 0.2 & $(-244,-5)$ \\
\hline Mode of transfers & $2.8(0.4)$ & $3.6(1)$ & $3.2(0.6)$ & -0.8 & $(-3.1,1.4)$ & 0.5 & $(-3.3,0.8)$ \\
\hline Total & $61065(2376)$ & $65464(2381)$ & $63423(1690)$ & -4399 & $(-11080,2283)$ & 0.2 & $(-10713,1773)$ \\
\hline
\end{tabular}




\begin{tabular}{|c|c|c|c|c|c|c|c|}
\hline $\begin{array}{c}\text { Costs } \\
\text { (Entire study period) }\end{array}$ & $\begin{array}{c}\text { Intervention } \\
(\mathrm{N}=69)\end{array}$ & $\begin{array}{c}\text { Control } \\
(\mathrm{N}=81)\end{array}$ & $\begin{array}{c}\text { Total } \\
(\mathrm{N}=150)\end{array}$ & $\begin{array}{c}\text { Mean } \\
\text { difference }\end{array}$ & Parametric $95 \% \mathrm{Cl}$ & P-value & $\begin{array}{c}\text { Bootstrap } \\
95 \% \mathrm{Cl}\end{array}$ \\
\hline & Mean (SE) & Mean (SE) & Mean (SE) & & & & \\
\hline Equipment & $87(2)$ & $\mathrm{n} / \mathrm{a}$ & $\mathrm{n} / \mathrm{a}$ & $n / a$ & $n / a$ & $\mathrm{n} / \mathrm{a}$ & $\mathrm{n} / \mathrm{a}$ \\
\hline Monitoring & $165(6)$ & $\mathrm{n} / \mathrm{a}$ & $\mathrm{n} / \mathrm{a}$ & $\mathrm{n} / \mathrm{a}$ & $\mathrm{n} / \mathrm{a}$ & $\mathrm{n} / \mathrm{a}$ & $\mathrm{n} / \mathrm{a}$ \\
\hline Point of care testing & $5.8(0.3)$ & $4.5(0.3)$ & $5.1(0.2)$ & 1.3 & $(0.5,2.1)$ & 0.002 & $(0.6,2.2)$ \\
\hline Length of stay & $68144(2563)$ & $71273(2101)$ & $69833(1636)$ & -3129 & $(-9616,3358)$ & 0.3 & $(-9577,3043)$ \\
\hline Medications & $79(2)$ & $78(1)$ & $78(1)$ & -2.7 & $(-2.7,5.5)$ & 0.5 & $(-3,5.5)$ \\
\hline Investigation & $1260(94)$ & $1471(115)$ & $1374(76)$ & -212 & $(-513,89)$ & 0.2 & $(-505,88)$ \\
\hline Blood transfusion products & $320(49)$ & $387(53)$ & $356(36)$ & -67 & $(-211,78)$ & 0.4 & $(-203,71)$ \\
\hline Medical treatment & $798(99)$ & $1062(131)$ & $941(85)$ & -264 & $(-598,70)$ & 0.1 & $(-587,45)$ \\
\hline Surgical procedures & 1047 (994) & 939 (848) & $989(645)$ & 109 & $(-2457,2674)$ & 0.9 & $(-2313,3007)$ \\
\hline Other procedures & $2(2)$ & $131(72)$ & $72(39)$ & -130 & $(-284,25)$ & 0.1 & $(-294,-7)$ \\
\hline Mode of transfers & $2.8(0.4)$ & $3.6(1)$ & $3.3(0.6)$ & -0.8 & $(-3.1,1.5)$ & 0.5 & $(-3.2,1)$ \\
\hline Total & 71910 (2779) & $75348(2476)$ & 73767 (1849) & -3439 & $(-10645,2939)$ & 0.4 & $(-10774,3896)$ \\
\hline
\end{tabular}


Table 4: Results of cost-effectiveness analyses (costs covering days 1 to 7 ) (£, 2016-17 prices)

\begin{tabular}{|c|c|c|c|c|c|c|c|c|c|c|c|c|c|}
\hline \multirow[t]{2}{*}{ Scenario } & \multicolumn{2}{|c|}{$\begin{array}{l}\text { Treatment group, } \\
\text { mean (SE) Cost }\end{array}$} & \multirow[t]{2}{*}{$\begin{array}{l}\text { Incremental } \\
\text { cost }\end{array}$} & \multicolumn{2}{|c|}{$\begin{array}{c}\text { Treatment } \\
\text { group } \\
\text { mean (SE) }\end{array}$} & \multirow[t]{2}{*}{$\begin{array}{c}\text { Incremental } \\
\text { effectiveness } \\
(95 \% \mathrm{Cl})\end{array}$} & \multirow[t]{2}{*}{ ICER } & \multicolumn{3}{|c|}{$\begin{array}{l}\text { Probability of } \\
\text { cost-effectiveness }\end{array}$} & \multicolumn{3}{|c|}{ Net monetary benefits } \\
\hline & CGM & Control & & CGM & Control & & & $\mathbf{P a}^{\mathbf{a}}$ & $\mathbf{P}^{b}$ & $\mathbf{P}^{\mathrm{c}}$ & $\begin{array}{c}\text { NMB }^{a} \\
(95 \% \mathrm{Cl})\end{array}$ & $\begin{array}{c}\text { NMB }^{\mathrm{b}} \\
(95 \% \mathrm{Cl})\end{array}$ & $\begin{array}{c}\text { NMBC }^{\mathrm{c}} \\
(95 \% \mathrm{Cl})\end{array}$ \\
\hline \multicolumn{14}{|c|}{ Base case analysis } \\
\hline $\begin{array}{r}\text { Imputed costs } \\
\text { and cases of } \\
\text { adequate } \\
\text { glucose control } \\
(80 \% \\
\text { threshold), } \\
\text { covariate } \\
\text { adjusted }\end{array}$ & $\begin{array}{r}10354 \\
(597)\end{array}$ & $\begin{array}{l}9749 \\
(282)\end{array}$ & $\begin{array}{r}605 \\
(-379,1589)\end{array}$ & $\begin{array}{r}0.92 \\
(0.05)\end{array}$ & $\begin{array}{r}0.68 \\
(0.05)\end{array}$ & $\begin{array}{r}0.23 \\
(0.07,0.4)\end{array}$ & 2583 & 0.31 & 0.86 & 0.97 & $\begin{array}{r}-276 \\
(-308,-245)\end{array}$ & $\begin{array}{r}718 \\
(677,759)\end{array}$ & $\begin{array}{r}1961 \\
(1899,2023)\end{array}$ \\
\hline \multicolumn{14}{|c|}{ Sensitivity analyses } \\
\hline $\begin{array}{r}\text { Complete case } \\
\text { attributable } \\
\text { costs and } \\
\text { cases of } \\
\text { adequate } \\
\text { glucose control } \\
(80 \% \text { threshold })\end{array}$ & $\begin{array}{r}11117 \\
(743)\end{array}$ & $\begin{array}{r}10013 \\
(370)\end{array}$ & $\begin{array}{r}1104 \\
(-39,2247)\end{array}$ & $\begin{array}{r}0.93 \\
(0.05)\end{array}$ & $\begin{array}{r}0.7 \\
(0.06)\end{array}$ & $\begin{array}{r}0.22 \\
(0.05,0.4)\end{array}$ & 4923 & 0.08 & 0.56 & 0.89 & $\begin{array}{r}-827 \\
(-864,-790)\end{array}$ & $\begin{array}{r}138 \\
(90,185)\end{array}$ & $\begin{array}{r}1344 \\
(1276,1413)\end{array}$ \\
\hline $\begin{array}{r}\text { Imputed costs } \\
\text { and cases of } \\
\text { adequate } \\
\text { glucose control } \\
(90 \% \\
\text { threshold), } \\
\text { covariate } \\
\text { adjusted }\end{array}$ & $\begin{array}{r}10354 \\
(597)\end{array}$ & $\begin{array}{l}9749 \\
(282)\end{array}$ & $\begin{array}{r}605 \\
(-379,1589)\end{array}$ & $\begin{array}{l}0.80 \\
(0.1)\end{array}$ & $\begin{array}{r}0.58 \\
(0.06)\end{array}$ & $\begin{array}{r}0.23 \\
(-0.03,0.48)\end{array}$ & 2670 & 0.33 & 0.81 & 0.93 & $\begin{array}{r}-266 \\
(-376,-157)\end{array}$ & $\begin{array}{r}752 \\
(581,923)\end{array}$ & $\begin{array}{r}2025 \\
(1740,2309)\end{array}$ \\
\hline
\end{tabular}




\begin{tabular}{|c|c|c|c|c|c|c|c|c|c|c|c|c|c|}
\hline \multirow{2}{*}{ Scenario } & \multicolumn{2}{|c|}{$\begin{array}{l}\text { Treatment group, } \\
\text { mean (SE) Cost }\end{array}$} & \multirow[t]{2}{*}{$\begin{array}{l}\text { Incremental } \\
\text { cost }\end{array}$} & \multicolumn{2}{|c|}{$\begin{array}{l}\text { Treatment } \\
\text { group } \\
\text { mean (SE) }\end{array}$} & \multirow[t]{2}{*}{$\begin{array}{c}\text { Incremental } \\
\text { effectiveness } \\
(95 \% \mathrm{Cl})\end{array}$} & \multirow[t]{2}{*}{ ICER } & \multicolumn{3}{|c|}{$\begin{array}{l}\text { Probability of } \\
\text { cost-effectiveness }\end{array}$} & \multicolumn{3}{|c|}{ Net monetary benefits } \\
\hline & CGM & Control & & CGM & Control & & & $\mathbf{P a}$ & $\mathbf{P}^{b}$ & $\mathbf{P}^{\mathrm{c}}$ & $\begin{array}{c}\text { NMB }^{a} \\
(95 \% \mathrm{Cl})\end{array}$ & $\begin{array}{c}\text { NMB }^{b} \\
(95 \% \mathrm{Cl})\end{array}$ & $\begin{array}{c}\text { NMBC }^{c} \\
(95 \% \mathrm{Cl})\end{array}$ \\
\hline $\begin{array}{r}\text { Imputed costs } \\
\text { and cases of } \\
\text { adequate } \\
\text { glucose control } \\
(70 \% \\
\text { threshold), } \\
\text { covariate } \\
\text { adjusted }\end{array}$ & $\begin{array}{r}10354 \\
(597)\end{array}$ & $\begin{array}{l}9749 \\
(282)\end{array}$ & $\begin{array}{r}605 \\
(-379,1589)\end{array}$ & $\begin{array}{r}0.97 \\
(0.04)\end{array}$ & $\begin{array}{r}0.75 \\
(0.05)\end{array}$ & $\begin{array}{r}0.21 \\
(0.06,0.36)\end{array}$ & 2870 & 0.27 & 0.85 & 0.97 & $\begin{array}{r}-292 \\
(-396,-189)\end{array}$ & $\begin{array}{r}621 \\
(499,742)\end{array}$ & $\begin{array}{r}1762 \\
(1590,1935)\end{array}$ \\
\hline $\begin{array}{r}\text { Imputed costs } \\
\text { and cases of } \\
\text { adequate } \\
\text { glucose control } \\
(60 \% \\
\text { threshold), } \\
\text { covariate } \\
\text { adjusted }\end{array}$ & $\begin{array}{r}10354 \\
(597)\end{array}$ & $\begin{array}{l}9749 \\
(282)\end{array}$ & $\begin{array}{r}605 \\
(-379,1589)\end{array}$ & $\begin{array}{r}0.97 \\
(0.03)\end{array}$ & $\begin{array}{r}0.83 \\
(0.04)\end{array}$ & $\begin{array}{r}0.14 \\
(0.04,0.25)\end{array}$ & 4223 & 0.26 & 0.65 & 0.90 & $\begin{array}{r}-370 \\
(-475,-265)\end{array}$ & $\begin{array}{r}233 \\
(114,352)\end{array}$ & $\begin{array}{r}987 \\
(835,1139)\end{array}$ \\
\hline \multicolumn{14}{|c|}{ Sub group analysis ${ }^{d}$} \\
\hline $\begin{array}{r}\text { Stratification by } \\
\text { centre } \\
\text { Cambridge N01 }\end{array}$ & $\begin{array}{l}12542 \\
(2275)\end{array}$ & $\begin{array}{l}9873 \\
(357)\end{array}$ & $\begin{array}{r}2670 \\
(-1819,7158)\end{array}$ & $\begin{array}{r}0.88 \\
(0.06)\end{array}$ & $\begin{array}{l}0.63 \\
(0.1)\end{array}$ & $\begin{array}{r}0.26 \\
(0.03,0.48)\end{array}$ & 10469 & 0.17 & 0.19 & 0.27 & $\begin{array}{r}-2444 \\
(-3015,-1874)\end{array}$ & $\begin{array}{r}-2251 \\
(-2821,-1681)\end{array}$ & $\begin{array}{rr} & -2009 \\
(-2582, & -1437)\end{array}$ \\
\hline $\begin{array}{r}\text { Stratification by } \\
\text { centre } \\
\text { Norwich N42 }\end{array}$ & $\begin{array}{r}7770 \\
(1163)\end{array}$ & $\begin{array}{r}10297 \\
(251)\end{array}$ & $\begin{array}{r}-2527 \\
(-4871,-182)\end{array}$ & 1 & $\begin{array}{r}0.86 \\
(0.12)\end{array}$ & $\begin{array}{r}0.14 \\
(-0.09,0.37)\end{array}$ & -17686 & 0.96 & 0.98 & 0.99 & $\begin{array}{r}3666 \\
(3345,3987)\end{array}$ & $\begin{array}{r}4087 \\
(3753,4420)\end{array}$ & $\begin{array}{r}4612 \\
(4251,4973)\end{array}$ \\
\hline
\end{tabular}




\begin{tabular}{|c|c|c|c|c|c|c|c|c|c|c|c|c|c|}
\hline \multirow[t]{2}{*}{ Scenario } & \multicolumn{2}{|c|}{$\begin{array}{l}\text { Treatment group, } \\
\text { mean (SE) Cost }\end{array}$} & \multirow[t]{2}{*}{$\begin{array}{l}\text { Incremental } \\
\text { cost }\end{array}$} & \multicolumn{2}{|c|}{$\begin{array}{l}\text { Treatment } \\
\text { group } \\
\text { mean (SE) }\end{array}$} & \multirow[t]{2}{*}{$\begin{array}{c}\text { Incremental } \\
\text { effectiveness } \\
(95 \% \mathrm{Cl})\end{array}$} & \multirow[t]{2}{*}{ ICER } & \multicolumn{3}{|c|}{$\begin{array}{l}\text { Probability of } \\
\text { cost-effectiveness }\end{array}$} & \multicolumn{3}{|c|}{ Net monetary benefits } \\
\hline & CGM & Control & & CGM & Control & & & $\mathbf{P a}^{\mathbf{a}}$ & $\mathbf{P}^{\mathrm{b}}$ & $\mathbf{P}^{\mathrm{c}}$ & $\begin{array}{c}\mathrm{NMB}^{\mathrm{a}} \\
(95 \% \mathrm{Cl})\end{array}$ & $\begin{array}{l}\mathrm{NMB}^{\mathrm{b}} \\
(95 \% \mathrm{Cl})\end{array}$ & $\begin{array}{c}\text { NMB }^{\mathrm{c}} \\
(95 \% \mathrm{Cl})\end{array}$ \\
\hline $\begin{array}{r}\text { Stratification by } \\
\text { centre } \\
\text { Luton \& } \\
\text { Dunstable N43 }\end{array}$ & $\begin{array}{r}10622 \\
(182)\end{array}$ & $\begin{array}{l}9309 \\
(686)\end{array}$ & $\begin{array}{r}1312 \\
(-88,2714)\end{array}$ & $\begin{array}{r}0.91 \\
(0.08)\end{array}$ & $\begin{array}{r}0.69 \\
(0.13)\end{array}$ & $\begin{array}{r}0.22 \\
(-0.06,0.49)\end{array}$ & 6056 & 0.19 & 0.28 & 0.49 & $\begin{array}{r}-982 \\
(-1196,-768)\end{array}$ & $\begin{array}{r}-495 \\
(-704,-285)\end{array}$ & $\begin{array}{r}114 \\
(-108,336)\end{array}$ \\
\hline 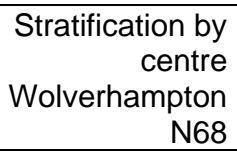 & $\begin{array}{l}9592 \\
(383)\end{array}$ & $\begin{array}{l}9470 \\
(788)\end{array}$ & $\begin{array}{r}122 \\
(-1517,1760)\end{array}$ & $\begin{array}{r}0.82 \\
(0.12)\end{array}$ & $\begin{array}{r}0.69 \\
(0.15)\end{array}$ & $\begin{array}{r}0.13 \\
(-0.26,0.51)\end{array}$ & 968 & 0.36 & 0.53 & 0.62 & $\begin{array}{r}-317 \\
(-498,-136)\end{array}$ & $\begin{array}{r}21 \\
(-192,234)\end{array}$ & $\begin{array}{r}444 \\
(179,708)\end{array}$ \\
\hline $\begin{array}{r}\text { Stratification by } \\
\text { centre } \\
\text { Southampton } \\
\text { N73 }\end{array}$ & $\begin{array}{l}9181 \\
(889)\end{array}$ & $\begin{array}{l}8112 \\
(546)\end{array}$ & $\begin{array}{r}1069 \\
(-1169,3307)\end{array}$ & 1 & $\begin{array}{l}0.83 \\
(0.1)\end{array}$ & $\begin{array}{r}0.17 \\
(-0.04,0.37)\end{array}$ & 6413 & 0.63 & 0.71 & 0.87 & $\begin{array}{r}824 \\
(291,1357)\end{array}$ & $\begin{array}{r}1582 \\
(1128,2036)\end{array}$ & $\begin{array}{r}2529 \\
(2100,2958)\end{array}$ \\
\hline $\begin{array}{r}\text { Stratification by } \\
\text { centre } \\
\text { Amsterdam } \\
\text { ND3 }\end{array}$ & $\begin{array}{r}10282 \\
(535)\end{array}$ & $\begin{array}{l}9290 \\
(853)\end{array}$ & $\begin{array}{r}992 \\
(-848,2832)\end{array}$ & $\begin{array}{r}1 \\
(0)\end{array}$ & $\begin{array}{r}0.75 \\
(0.17)\end{array}$ & $\begin{array}{r}0.25 \\
(-0.08,0.58)\end{array}$ & 3967 & 0.40 & 0.56 & 0.72 & $\begin{array}{r}-758 \\
(-859,-658)\end{array}$ & $\begin{array}{r}-462 \\
(-583,-341)\end{array}$ & $\begin{array}{r}-92 \\
(-302,118)\end{array}$ \\
\hline $\begin{array}{r}\text { Stratification by } \\
\text { gestational age } \\
\text { at birth } \\
\text { Extreme } \\
\text { preterm } \\
(<28 \text { weeks })\end{array}$ & $\begin{array}{r}10035 \\
(292)\end{array}$ & $\begin{array}{r}10018 \\
(254)\end{array}$ & $\begin{array}{r}17 \\
(-820,854)\end{array}$ & $\begin{array}{r}0.88 \\
(0.06)\end{array}$ & $\begin{array}{r}0.64 \\
(0.06)\end{array}$ & $\begin{array}{r}0.24 \\
(0.08,0.4)\end{array}$ & 71 & 0.69 & 0.99 & 1 & $\begin{array}{r}221 \\
(133,310)\end{array}$ & $\begin{array}{r}1191 \\
(1067,1315)\end{array}$ & $\begin{array}{r}2403 \\
(2212,2594)\end{array}$ \\
\hline $\begin{array}{r}\text { Stratification by } \\
\text { gestational age } \\
\text { at birth } \\
\text { Very preterm } \\
\text { (28 weeks to } 32 \\
\text { weeks) }\end{array}$ & $\begin{array}{l}11531 \\
(1724)\end{array}$ & $\begin{array}{l}8937 \\
(370)\end{array}$ & $\begin{array}{r}2594 \\
(-785,5972)\end{array}$ & $\begin{array}{r}0.93 \\
(0.05)\end{array}$ & $\begin{array}{r}0.79 \\
(0.08)\end{array}$ & $\begin{array}{r}0.14 \\
(-0.05,0.33)\end{array}$ & 18501 & 0.03 & 0.16 & 0.29 & $\begin{array}{r}-2541 \\
(-2886,-2196)\end{array}$ & $\begin{array}{r}-1947 \\
(-2305,-1589)\end{array}$ & $\begin{array}{r}-1204 \\
(-1601,-807)\end{array}$ \\
\hline
\end{tabular}




\begin{tabular}{|c|c|c|c|c|c|c|c|c|c|c|c|c|c|}
\hline \multirow{2}{*}{ Scenario } & \multicolumn{2}{|c|}{$\begin{array}{l}\text { Treatment group, } \\
\text { mean (SE) Cost }\end{array}$} & \multirow[t]{2}{*}{$\begin{array}{l}\text { Incremental } \\
\text { cost }\end{array}$} & \multicolumn{2}{|c|}{$\begin{array}{l}\text { Treatment } \\
\text { group } \\
\text { mean (SE) }\end{array}$} & \multirow[t]{2}{*}{$\begin{array}{c}\text { Incremental } \\
\text { effectiveness } \\
(95 \% \mathrm{Cl})\end{array}$} & \multirow[t]{2}{*}{ ICER } & \multicolumn{3}{|c|}{$\begin{array}{l}\text { Probability of } \\
\text { cost-effectiveness }\end{array}$} & \multicolumn{3}{|c|}{ Net monetary benefits } \\
\hline & CGM & Control & & CGM & Control & & & $\mathbf{P a}$ & $\mathbf{P}^{\mathbf{b}}$ & $\mathbf{P}^{\mathrm{c}}$ & $\begin{array}{c}\mathrm{NMB}^{\mathrm{a}} \\
(95 \% \mathrm{Cl})\end{array}$ & $\begin{array}{c}\text { NMB }^{\mathbf{b}} \\
(95 \% \mathrm{Cl})\end{array}$ & $\begin{array}{c}\text { NMB }^{\mathrm{c}} \\
(95 \% \mathrm{Cl})\end{array}$ \\
\hline $\begin{array}{r}\text { Stratification by } \\
\text { gender } \\
\text { Male }\end{array}$ & $\begin{array}{l}9539 \\
(331)\end{array}$ & $\begin{array}{l}9735 \\
(299)\end{array}$ & $\begin{array}{r}-196 \\
(-1041,650)\end{array}$ & $\begin{array}{r}0.91 \\
(0.05)\end{array}$ & $\begin{array}{r}0.60 \\
(0.08)\end{array}$ & $\begin{array}{r}0.31 \\
(0.12,0.5)\end{array}$ & -632 & 0.88 & 1 & 1 & $\begin{array}{r}498 \\
(410,585)\end{array}$ & $\begin{array}{r}1734 \\
(1608,1859)\end{array}$ & $\begin{array}{r}3278 \\
(3074,3483)\end{array}$ \\
\hline $\begin{array}{r}\text { Stratification by } \\
\text { gender } \\
\text { Female }\end{array}$ & $\begin{array}{r}11666 \\
(1595)\end{array}$ & $\begin{array}{l}9517 \\
(269)\end{array}$ & $\begin{array}{r}2150 \\
(-1037,5336)\end{array}$ & $\begin{array}{r}0.88 \\
(0.06)\end{array}$ & $\begin{array}{r}0.78 \\
(0.07)\end{array}$ & $\begin{array}{r}0.10 \\
(-0.07,0.27)\end{array}$ & 21496 & 0.08 & 0.22 & 0.27 & $\begin{array}{r}-2077 \\
(-2400,-1753)\end{array}$ & $\begin{array}{r}-1678 \\
(-2010,-1346)\end{array}$ & $\begin{array}{r}-1179 \\
(-1540,-819)\end{array}$ \\
\hline \multicolumn{14}{|c|}{ Secondary analysis } \\
\hline & CGM & Control & & CGM & Control & & & $\mathbf{p e}^{\mathbf{e}}$ & $P^{f}$ & $\mathrm{pg}$ & $\begin{array}{c}\text { NMBe }^{\mathrm{e}} \\
(95 \% \mathrm{Cl})\end{array}$ & $\begin{array}{c}\text { NMB }^{f} \\
(95 \% \mathrm{Cl})\end{array}$ & $\begin{array}{c}\text { NMBg } \\
(95 \% \mathrm{Cl})\end{array}$ \\
\hline $\begin{array}{r}\text { Imputed costs } \\
\text { and cases of } \\
\text { BPD averted, } \\
\text { covariate } \\
\text { adjusted }\end{array}$ & $\begin{array}{r}10354 \\
(597)\end{array}$ & $\begin{array}{l}9749 \\
(282)\end{array}$ & $\begin{array}{r}605 \\
(-379,1589)\end{array}$ & $\begin{array}{r}0.66 \\
(0.17)\end{array}$ & $\begin{array}{r}0.52 \\
(0.12)\end{array}$ & $\begin{array}{r}0.14 \\
(-0.28,0.56)\end{array}$ & 4286 & 0.65 & 0.73 & 0.74 & $\begin{array}{r}962 \\
(819,1105)\end{array}$ & $\begin{array}{r}3936 \\
(3531,4342)\end{array}$ & $\begin{array}{r}6910 \\
(6240,7580)\end{array}$ \\
\hline $\begin{array}{r}\text { Imputed costs } \\
\text { and cases of } \\
\text { NEC averted, } \\
\text { covariate } \\
\text { adjusted }\end{array}$ & $\begin{array}{r}10354 \\
(597)\end{array}$ & $\begin{array}{l}9749 \\
(282)\end{array}$ & $\begin{array}{r}605 \\
(-379,1589)\end{array}$ & $\begin{array}{r}0.87 \\
(0.05)\end{array}$ & $\begin{array}{r}0.71 \\
(0.06)\end{array}$ & $\begin{array}{r}0.16 \\
(0,0.33)\end{array}$ & 3697 & 0.82 & 0.95 & 0.97 & $\begin{array}{r}1085 \\
(885,1285)\end{array}$ & $\begin{array}{r}4296 \\
(3781,4812)\end{array}$ & $\begin{array}{r}7508 \\
(6662,8354)\end{array}$ \\
\hline
\end{tabular}

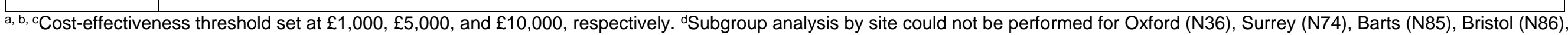
Leeds (N87), Leicester (N88), or Barcelona (SP3) due to insufficient number of observations. e, f, gCost-effectiveness threshold set at £10,000, £30,000, and £50,000, respectively 
Table 5: Results of cost-effectiveness analyses over follow-up period extending to 36 weeks' corrected gestation (£, 2016-17 prices)

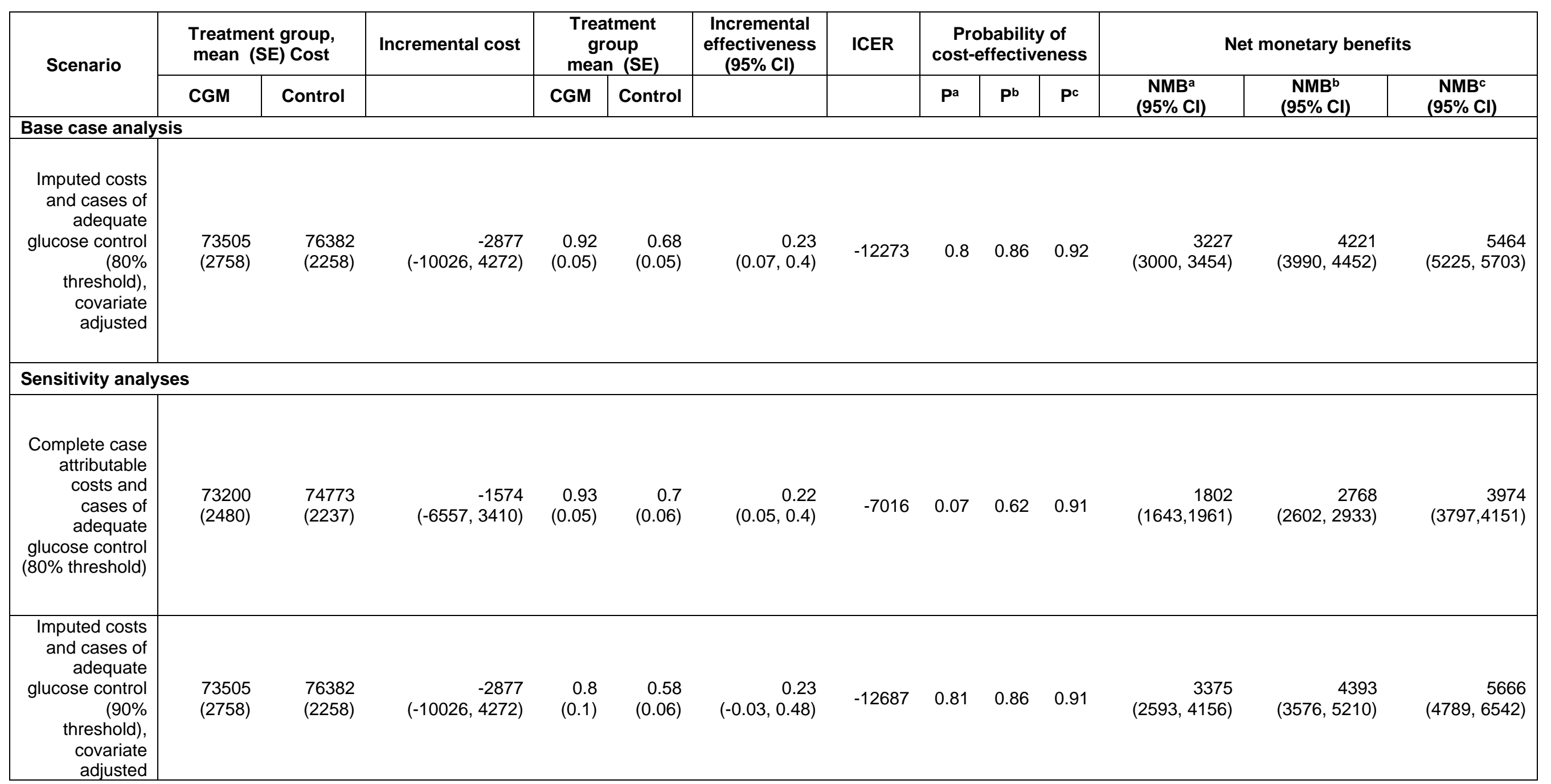




\begin{tabular}{|c|c|c|c|c|c|c|c|c|c|c|c|c|c|}
\hline \multirow{2}{*}{ Scenario } & \multicolumn{2}{|c|}{$\begin{array}{l}\text { Treatment group, } \\
\text { mean (SE) Cost }\end{array}$} & \multirow[t]{2}{*}{ Incremental cost } & \multicolumn{2}{|c|}{$\begin{array}{l}\text { Treatment } \\
\text { group } \\
\text { mean (SE) }\end{array}$} & \multirow[t]{2}{*}{$\begin{array}{c}\text { Incremental } \\
\text { effectiveness } \\
(95 \% \mathrm{Cl})\end{array}$} & \multirow[t]{2}{*}{ ICER } & \multicolumn{3}{|c|}{$\begin{array}{l}\text { Probability of } \\
\text { cost-effectiveness }\end{array}$} & \multicolumn{3}{|c|}{ Net monetary benefits } \\
\hline & CGM & Control & & CGM & Control & & & $\mathbf{P a}$ & $\mathbf{P}^{\mathrm{b}}$ & $\mathbf{P}^{\mathbf{c}}$ & $\begin{array}{c}\text { NMB }^{a} \\
(95 \% \mathrm{Cl})\end{array}$ & $\begin{array}{c}\text { NMB }^{b} \\
(95 \% \mathrm{Cl})\end{array}$ & $\begin{array}{c}\text { NMB }^{c} \\
(95 \% \mathrm{Cl})\end{array}$ \\
\hline $\begin{array}{r}\text { Imputed costs } \\
\text { and cases of } \\
\text { adequate } \\
\text { glucose control } \\
(70 \% \\
\text { threshold), } \\
\text { covariate } \\
\text { adjusted }\end{array}$ & $\begin{array}{l}73505 \\
(2758)\end{array}$ & $\begin{array}{l}76382 \\
(2258)\end{array}$ & $\begin{array}{r}-2877 \\
(-10026,4272)\end{array}$ & $\begin{array}{r}0.97 \\
(0.04)\end{array}$ & $\begin{array}{r}0.75 \\
(0.05)\end{array}$ & $\begin{array}{r}0.21 \\
(0.06,0.36)\end{array}$ & -13637 & 0.81 & 0.85 & 0.9 & $\begin{array}{r}3348 \\
(2572,4124)\end{array}$ & $\begin{array}{r}4262 \\
(3476,5047)\end{array}$ & $\begin{array}{r}5403 \\
(4599,6207)\end{array}$ \\
\hline $\begin{array}{r}\text { Imputed costs } \\
\text { and cases of } \\
\text { adequate } \\
\text { glucose control } \\
(60 \% \\
\text { threshold), } \\
\text { covariate } \\
\text { adjusted }\end{array}$ & $\begin{array}{l}73505 \\
(2758)\end{array}$ & $\begin{array}{l}76382 \\
(2258)\end{array}$ & $\begin{array}{r}-2877 \\
(-10026,4272)\end{array}$ & $\begin{array}{r}0.97 \\
(0.03)\end{array}$ & $\begin{array}{r}0.83 \\
(0.04)\end{array}$ & $\begin{array}{r}0.14 \\
(0.04,0.25)\end{array}$ & -20066 & 0.81 & 0.83 & 0.89 & $\begin{array}{r}3271 \\
(2494,4048)\end{array}$ & $\begin{array}{r}3874 \\
(3085,4663)\end{array}$ & $\begin{array}{r}4628 \\
(3820,5436)\end{array}$ \\
\hline \multicolumn{14}{|c|}{ Sub group analysis ${ }^{d}$} \\
\hline $\begin{array}{r}\text { Stratification by } \\
\text { centre } \\
\text { Cambridge N01 }\end{array}$ & $\begin{array}{l}82336 \\
(2895)\end{array}$ & $\begin{array}{l}79688 \\
(4287)\end{array}$ & $\begin{array}{r}2648 \\
(-7706,13002)\end{array}$ & $\begin{array}{r}0.88 \\
(0.06)\end{array}$ & $\begin{array}{l}0.63 \\
(0.1)\end{array}$ & $\begin{array}{r}0.26 \\
(0.03,0.48)\end{array}$ & 10385 & 0.3 & 0.38 & 0.56 & $\begin{array}{r}-1997 \\
(-3043,-951)\end{array}$ & $\begin{array}{r}-963 \\
(-2006,81)\end{array}$ & $\begin{array}{r}330 \\
(-722,1381)\end{array}$ \\
\hline $\begin{array}{r}\text { Stratification by } \\
\text { centre } \\
\text { Norwich N42 }\end{array}$ & $\begin{array}{r}63545 \\
(19515)\end{array}$ & $\begin{array}{l}73956 \\
(4990)\end{array}$ & $\begin{array}{r}-10411 \\
(-48985,28162)\end{array}$ & 1 & $\begin{array}{r}0.86 \\
(0.12)\end{array}$ & $\begin{array}{r}0.14 \\
(-0.09,0.37)\end{array}$ & -72879 & 0.79 & 0.79 & 0.82 & $\begin{array}{r}12753 \\
(8126,17379)\end{array}$ & $\begin{array}{r}13695 \\
(9059,18331)\end{array}$ & $\begin{array}{r}14874 \\
(10222,19525)\end{array}$ \\
\hline
\end{tabular}




\begin{tabular}{|c|c|c|c|c|c|c|c|c|c|c|c|c|c|}
\hline \multirow[t]{2}{*}{ Scenario } & \multicolumn{2}{|c|}{$\begin{array}{l}\text { Treatment group, } \\
\text { mean (SE) Cost }\end{array}$} & \multirow[t]{2}{*}{ Incremental cost } & \multicolumn{2}{|c|}{$\begin{array}{l}\text { Treatment } \\
\text { group } \\
\text { mean (SE) }\end{array}$} & \multirow[t]{2}{*}{$\begin{array}{c}\text { Incremental } \\
\text { effectiveness } \\
(95 \% \mathrm{Cl})\end{array}$} & \multirow[t]{2}{*}{ ICER } & \multicolumn{3}{|c|}{$\begin{array}{l}\text { Probability of } \\
\text { cost-effectiveness }\end{array}$} & \multicolumn{3}{|c|}{ Net monetary benefits } \\
\hline & CGM & Control & & CGM & Control & & & $\mathbf{P a}$ & $\mathbf{P}^{\mathrm{b}}$ & $\mathbf{P}^{\mathbf{c}}$ & $\begin{array}{c}\text { NMB }^{a} \\
(95 \% \mathrm{Cl})\end{array}$ & $\begin{array}{c}\text { NMB }^{b} \\
(95 \% \mathrm{Cl})\end{array}$ & $\begin{array}{c}\text { NMBC }^{\text {c }} \\
(95 \% \mathrm{Cl})\end{array}$ \\
\hline $\begin{array}{r}\text { Stratification by } \\
\text { centre } \\
\text { Luton \& } \\
\text { Dunstable N43 }\end{array}$ & $\begin{array}{l}70091 \\
(6103)\end{array}$ & $\begin{array}{l}74115 \\
(4544)\end{array}$ & $\begin{array}{r}-4024 \\
(-18633,10586)\end{array}$ & $\begin{array}{r}0.91 \\
(0.08)\end{array}$ & $\begin{array}{r}0.69 \\
(0.13)\end{array}$ & $\begin{array}{r}0.22 \\
(-0.06,0.49)\end{array}$ & -18561 & 0.74 & 0.77 & 0.8 & $\begin{array}{r}4385 \\
(2910,5860)\end{array}$ & $\begin{array}{r}5208 \\
(3714,6701)\end{array}$ & $\begin{array}{r}6236 \\
(4708,7764)\end{array}$ \\
\hline $\begin{array}{r}\text { Stratification by } \\
\text { centre } \\
\text { Wolverhampton } \\
\text { N68 }\end{array}$ & $\begin{array}{l}79446 \\
(6431)\end{array}$ & $\begin{array}{l}88220 \\
(5321)\end{array}$ & $\begin{array}{r}-8774 \\
(-25199,7651)\end{array}$ & $\begin{array}{r}0.82 \\
(0.12)\end{array}$ & $\begin{array}{r}0.69 \\
(0.15)\end{array}$ & $\begin{array}{r}0.13 \\
(-0.26,0.51)\end{array}$ & -69708 & 0.79 & 0.8 & 0.81 & $\begin{array}{r}7539 \\
(5856,9222)\end{array}$ & $\begin{array}{r}7954 \\
(6170,9737)\end{array}$ & $\begin{array}{r}8473 \\
(6553,10392)\end{array}$ \\
\hline $\begin{array}{r}\text { Stratification by } \\
\text { centre } \\
\text { Southampton } \\
\text { N73 }\end{array}$ & $\begin{array}{r}56614 \\
(12085)\end{array}$ & $\begin{array}{l}61969 \\
(7603)\end{array}$ & $\begin{array}{r}-5355 \\
(-32051,21341)\end{array}$ & 1 & $\begin{array}{l}0.83 \\
(0.1)\end{array}$ & $\begin{array}{r}0.17 \\
(-0.04,0.37)\end{array}$ & -32129 & 0.81 & 0.81 & 0.82 & $\begin{array}{r}5994 \\
(2283,9705)\end{array}$ & $\begin{array}{r}6904 \\
(3220,10589)\end{array}$ & $\begin{array}{r}8043 \\
(4386,11700)\end{array}$ \\
\hline $\begin{array}{r}\text { Stratification by } \\
\text { centre } \\
\text { Amsterdam } \\
\text { ND3 }\end{array}$ & $\begin{array}{r}72631 \\
(16207)\end{array}$ & $\begin{array}{l}75867 \\
(8455)\end{array}$ & $\begin{array}{r}-3236 \\
(-38650,32177)\end{array}$ & $\begin{array}{r}1 \\
(0)\end{array}$ & $\begin{array}{r}0.75 \\
(0.17)\end{array}$ & $\begin{array}{r}0.25 \\
(-0.08,0.58)\end{array}$ & -12945 & 0.67 & 0.68 & 0.71 & $\begin{array}{r}4415 \\
(162,8669)\end{array}$ & $\begin{array}{r}5810 \\
(1521,10099)\end{array}$ & $\begin{array}{r}7553 \\
(3212,11893)\end{array}$ \\
\hline $\begin{array}{r}\text { Stratification by } \\
\text { gestational age } \\
\text { at birth } \\
\text { Extreme } \\
\text { preterm } \\
(<28 \text { weeks })\end{array}$ & $\begin{array}{l}84532 \\
(2548)\end{array}$ & $\begin{array}{l}87024 \\
(2423)\end{array}$ & $\begin{array}{r}-2492 \\
(-8872,3888)\end{array}$ & $\begin{array}{r}0.88 \\
(0.06)\end{array}$ & $\begin{array}{r}0.64 \\
(0.06)\end{array}$ & $\begin{array}{r}0.24 \\
(0.08,0.4)\end{array}$ & -10443 & 0.81 & 0.88 & 0.91 & $\begin{array}{r}2524 \\
(1874,3174)\end{array}$ & $\begin{array}{r}3493 \\
(2824,4162)\end{array}$ & $\begin{array}{r}4705 \\
(4004,5406)\end{array}$ \\
\hline $\begin{array}{r}\text { Stratification by } \\
\text { gestational age } \\
\text { at birth } \\
\text { Very preterm } \\
\text { (28 weeks to } 32 \\
\text { weeks) }\end{array}$ & $\begin{array}{l}59983 \\
(3187)\end{array}$ & $\begin{array}{l}57829 \\
(2146)\end{array}$ & $\begin{array}{r}2154 \\
(-5541,9849)\end{array}$ & $\begin{array}{r}0.93 \\
(0.05)\end{array}$ & $\begin{array}{r}0.79 \\
(0.08)\end{array}$ & $\begin{array}{r}0.14 \\
(-0.05,0.33)\end{array}$ & 15365 & 0.37 & 0.4 & 0.45 & 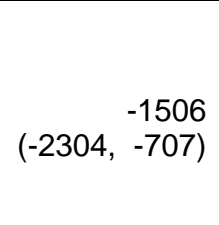 & $\begin{array}{r}-911 \\
(-1720,-102)\end{array}$ & $\begin{array}{r}-169 \\
(-1001,664)\end{array}$ \\
\hline
\end{tabular}




\begin{tabular}{|c|c|c|c|c|c|c|c|c|c|c|c|c|c|}
\hline \multirow{2}{*}{ Scenario } & \multicolumn{2}{|c|}{$\begin{array}{l}\text { Treatment group, } \\
\text { mean (SE) Cost }\end{array}$} & \multirow[t]{2}{*}{ Incremental cost } & \multicolumn{2}{|c|}{$\begin{array}{l}\text { Treatment } \\
\text { group } \\
\text { mean (SE) }\end{array}$} & \multirow[t]{2}{*}{$\begin{array}{c}\text { Incremental } \\
\text { effectiveness } \\
(95 \% \mathrm{Cl})\end{array}$} & \multirow[t]{2}{*}{ ICER } & \multicolumn{3}{|c|}{$\begin{array}{l}\text { Probability of } \\
\text { cost-effectiveness }\end{array}$} & \multicolumn{3}{|c|}{ Net monetary benefits } \\
\hline & CGM & Control & & CGM & Control & & & $\mathbf{P a}$ & $\mathbf{P}^{\mathbf{b}}$ & $\mathbf{P}^{\mathrm{c}}$ & $\begin{array}{c}\mathrm{NMB}^{\mathrm{a}} \\
(95 \% \mathrm{Cl})\end{array}$ & $\begin{array}{c}\mathrm{NMB}^{\mathrm{b}} \\
(95 \% \mathrm{Cl})\end{array}$ & $\begin{array}{c}\text { NMBC }^{\mathbf{c}} \\
(95 \% \mathrm{Cl})\end{array}$ \\
\hline $\begin{array}{r}\text { Stratification by } \\
\text { gender } \\
\text { Male }\end{array}$ & $\begin{array}{l}74004 \\
(3800)\end{array}$ & $\begin{array}{l}81783 \\
(3860)\end{array}$ & $\begin{array}{r}-7779 \\
(-17801,2243)\end{array}$ & $\begin{array}{r}0.91 \\
(0.05)\end{array}$ & $\begin{array}{r}0.6 \\
(0.08)\end{array}$ & $\begin{array}{r}0.31 \\
(0.12,0.5)\end{array}$ & -25123 & 0.93 & 0.96 & 0.99 & $\begin{array}{r}7580 \\
(6559,8602)\end{array}$ & $\begin{array}{r}8816 \\
(7763,9870)\end{array}$ & 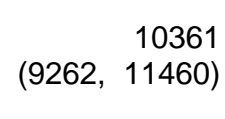 \\
\hline \multicolumn{14}{|c|}{ Secondary analysis } \\
\hline & CGM & Control & & CGM & Control & & & $\mathbf{p e}$ & $P^{f}$ & $\mathrm{pg}$ & $\begin{array}{c}\text { NMBe } \\
(95 \% \mathrm{Cl})\end{array}$ & $\begin{array}{c}\text { NMB }^{f} \\
(95 \% \mathrm{Cl})\end{array}$ & $\begin{array}{c}\text { NMBg } \\
(95 \% \mathrm{Cl})\end{array}$ \\
\hline $\begin{array}{r}\text { Imputed costs } \\
\text { and cases of } \\
\text { BPD averted, } \\
\text { covariate } \\
\text { adjusted }\end{array}$ & $\begin{array}{l}73505 \\
(2758)\end{array}$ & $\begin{array}{l}76382 \\
(2258)\end{array}$ & $\begin{array}{r}-2877 \\
(-10026,4272)\end{array}$ & $\begin{array}{r}0.66 \\
(0.17)\end{array}$ & $\begin{array}{r}0.52 \\
(0.12)\end{array}$ & $\begin{array}{r}0.14 \\
(-0.28,0.56)\end{array}$ & ---20368 & 0.82 & 0.82 & 0.81 & $\begin{array}{r}4466 \\
(4167,4 \\
764)\end{array}$ & $\begin{array}{l}7440 \\
(6920,7 \\
959)\end{array}$ & $\begin{array}{l}10414 \\
(9645,1 \\
1183)\end{array}$ \\
\hline $\begin{array}{r}\text { Imputed costs } \\
\text { and cases of } \\
\text { NEC averted, } \\
\text { covariate } \\
\text { adjusted }\end{array}$ & $\begin{array}{l}73505 \\
(2758)\end{array}$ & $\begin{array}{l}76382 \\
(2258)\end{array}$ & $\begin{array}{r}-2877 \\
(-10026,4272)\end{array}$ & $\begin{array}{r}0.87 \\
(0.05)\end{array}$ & $\begin{array}{r}0.71 \\
(0.06)\end{array}$ & $\begin{array}{r}0.16 \\
(0,0.33)\end{array}$ & -17568 & 0.88 & 0.94 & 0.97 & $\begin{array}{r}4726 \\
(3923,5529)\end{array}$ & $\begin{array}{r}7937 \\
(6986,8888)\end{array}$ & $\begin{array}{r}11149 \\
(9971,12327)\end{array}$ \\
\hline
\end{tabular}

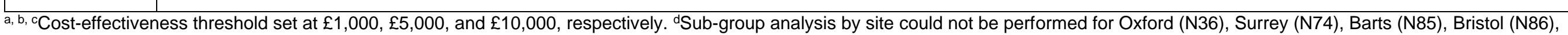
Leeds (N87), Leicester (N88), or Barcelona (SP3) due to insufficient number of observations. e, f, gCost-effectiveness threshold set at £10,000, £30,000, and £50,000, respectively 
